\title{
Lithographic Patterning of Photoreactive Cell-Adhesive Proteins
}

\author{
Isaac S. Carrico ${ }^{1}$, Stacey A. Maskarinec ${ }^{1}$, Sarah C. Heilshorn ${ }^{1}$, Marissa L. Mock ${ }^{1}$, Julie C. \\ Liu $^{1}$, Paul J. Nowatzki ${ }^{1}$, Christian Franck ${ }^{2}$, Guruswami Ravichandran ${ }^{2}$, and David A. \\ Tirrell $1{ }^{*}$ \\ 1 Division of Chemistry and Chemical Engineering, California Institute of Technology, Pasadena, CA 91125 \\ 2 Division of Engineering and Applied Science, California Institute of Technology, Pasadena, CA 91125
}

Control of the spatial arrangement of proteins on surfaces is essential in a number of emerging technologies, including protein microarrays, biosensors, ${ }_{1}^{1}$ tissue engineering, and regenerative medicine. ${ }^{2}$ Patterning is also a powerful tool in cell biology, wherein cell arrays are used to elucidate the factors that mediate migration, proliferation, and cell-cell interactions. ${ }^{3}$ Although photolithography holds a preeminent place as a patterning method in the microelectronics industry, optical lithography of proteins has been hampered by the need either to use traditional chemical photoresists or to modify proteins chemically by attachment of photoreactive functional groups; both methods can compromise protein function. ${ }^{4}$

Production of a protein "photoresist" without the need for post-translational chemical modification would require an intrinsically photoreactive protein. Recently, the incorporation of photo-reactive, non-canonical amino acids into proteins via site-specific ${ }^{5}$ and residuespecific techniques has been reported. ${ }^{6}$ Here we describe the microbial expression of artificial proteins bearing the photosensitive non-canonical amino acid para-azidophenylalanine $\left(p \mathrm{~N}_{3} \mathrm{Phe}\right)$. The recombinant proteins, designated artificial extracellular matrix proteins with aryl azides $\left(\mathrm{aECM}-\mathrm{N}_{3}\right)$, belong to a family of engineered proteins designed to exhibit mechanical properties similar to those of native elastins ${ }^{7}$ and to support adhesion of mammalian cells through cell-binding domains (CS5 or RGD) derived from fibronectin (Fig 1A). ${ }^{8}$ These proteins can be crosslinked efficiently upon irradiation at $365 \mathrm{~nm}$. The physical properties of the crosslinked films can be controlled by changing the $p \mathrm{~N}_{3}$ Phe content, and thin films can be patterned on surfaces via photolithographic techniques. We demonstrate the utility of the method by creating cell arrays through selective cell attachment to photolithographically prepared protein patterns.

aECM-N $\mathrm{N}_{3}$ variants were expressed in Escherichia coli cultures supplemented with $p \mathrm{~N}_{3}$ Phe (Supporting Information). Incorporation of $p \mathrm{~N}_{3}$ Phe into the recombinant proteins relies on activation of the photosensitive amino acid by the phenylalanyl-tRNA synthetase (PheRS) of the bacterial expression host. The PheRS used for this study was a previously characterized mutant with relaxed substrate specificity. ${ }^{9}$ This method results in statistical decoding of phenylalanine (Phe) codons placed at regular intervals in the coding sequence. ${ }^{9}$ Proteins were expressed in a Phe-auxotrophic E. coli strain and purified by exploiting the temperaturedependent phase behavior of proteins that contain elastin-like repeats. ${ }^{10}$ Incorporation efficiency was determined by integration of the aromatic proton signals in the ${ }^{1} \mathrm{H}$ NMR spectra of the purified proteins; the extent of Phe replacement varied from $13 \%$ to 53\%, depending on the concentration of $p \mathrm{~N}_{3} \mathrm{Phe}$ in the expression medium (Supporting Information).

E-mail: tirrell@caltech.edu. 
Understanding the response of the photoreactive protein to irradiation is crucial for highresolution pattern formation. We measured the rate of azide decomposition under irradiation by monitoring loss of the characteristic infrared asymmetric stretch at $2130 \mathrm{~cm}^{-1}$ (Fig. 1B). ${ }^{11}$ Measurements were performed on thin films of CS5- $\mathrm{N}_{3}$ spin-coated directly onto zinc selenide wafers and irradiated using a Karl Suss contact aligner filtered to $365 \mathrm{~nm}$ in constant intensity $\left(7 \mathrm{~mW} / \mathrm{cm}^{2}\right)$ mode, with a quartz wafer in place of the mask. Azide loss under these conditions was rapid, following first-order kinetics with a half-life of 34 seconds (Fig. 1C). It is noteworthy that none of the other infrared bands was noticeably altered, indicating that irradiation under the conditions used here activates the aryl azide without substantial modification of the other canonical amino acids. Aryl azides have been used previously to effect photochemical crosslinking in protein and nucleic acid systems. ${ }^{12}$

Elastic moduli of irradiated CS5-N $\mathrm{N}_{3}$ films were determined by uniaxial tensile testing under simulated physiological conditions (Fig. 1D). As expected, the elastic modulus correlated with the extent of $p \mathrm{~N}_{3}$ Phe incorporation. Irradiated CS5- $\mathrm{N}_{3}$ films in which 30, 41, or 53\% of the encoded Phe residues were replaced by $p \mathrm{~N}_{3}$ Phe yielded elastic moduli of $0.53 \pm 0.10,0.94 \pm$ 0.09 , and $1.39 \pm 0.09 \mathrm{MPa}$, respectively, values near the range characteristic of elastins $(0.3-$ $0.6 \mathrm{MPa}){ }^{7}$ Replacement of less than $20 \%$ of the encoded Phe residues produced films too weak to test, and films made without $p \mathrm{~N}_{3}$ Phe yielded no evidence of crosslinking. The capacity to vary the modulus by altering the $p \mathrm{~N}_{3}$ Phe concentration in the expression medium is an attractive feature of this method, as recent work has highlighted the role of mechanical transduction mechanisms in mediating the physiology of adherent cells. ${ }^{13}$

To investigate the potential of photoreactive proteins as substrates for studies of cell adhesion and growth, we created patterns of adherent fibroblasts on proteins patterned by photolithography. Protein films created by spin coating $12.5 \mathrm{mg} / \mathrm{mL}$ solutions of RGD- $\mathrm{N}_{3}$ in dimethylsulfoxide directly on poly(ethylene oxide) (PEO)-coated glass slides were clear and homogeneous by optical microscopy. Protein films were irradiated for 60 seconds at $365 \mathrm{~nm}$ through a chrome-on-quartz mask. Stripping of the masked areas was accomplished by washing in $6 \mathrm{M}$ guanidine hydrochloride.

Fluorescence immunolabeling with an anti-T7 tag antibody showed that the protein was localized only within the irradiated areas of the pattern. Films prepared from protein lacking $p \mathrm{~N}_{3}$ Phe formed no detectable patterns even after prolonged exposure. Non-contact atomic force microscopy (AFM) of RGD-N 3 patterns revealed uniform protein films. Films spun at $1000 \mathrm{rpm}$ were 467 or $750 \mathrm{~nm}$ thick when imaged dry or hydrated, respectively. (Supporting Information).

To create cell arrays, Rat-1 fibroblasts were deposited on RGD-N ${ }_{3}$ patterns in the absence of serum. After 4 hours of incubation, the unattached cells were removed by mild washing with phosphate buffered saline (PBS) revealing cell patterns (Fig. 2). Cell monolayers in the interior of the protein regions were indistinguishable from monolayers grown on fibronectin coatings; however, cells positioned along the RGD- $\mathrm{N}_{3}$ pattern edges were elongated parallel to the pattern border, consistent with previous studies (Supporting Information). ${ }^{14}$

To determine whether cells specifically recognize the RGD cell-binding domain, we compared cell spreading on uniformly photocrosslinked RGD- $\mathrm{N}_{3}$ and RDG- $\mathrm{N}_{3}$ (sequence-altered, negative control) films (Fig. 3). After 4 hours of incubation, Rat-1 cells spread well on RGD$\mathrm{N}_{3}$ films, although the extent of spreading was reduced in comparison to that observed on the fibronectin control. In contrast, cells did not spread on RDG- $\mathrm{N}_{3}$ and resembled cells plated on bovine serum albumin (BSA).

The availability of intrinsically photoreactive proteins enables new approaches to protein patterning. The technical simplicity of the method allows rapid production of samples with a 
wide variety of feature shapes and sizes, while permitting straightforward engineering of the elastic modulus of the crosslinked protein. The method is a promising approach to the study of adherent cells, providing control over mechanical properties, ligand-receptor interactions, and geometric shape. Applications in medical devices, tissue engineering, and array technologies are readily imagined.

\section{Supplementary Material}

Refer to Web version on PubMed Central for supplementary material.

\section{Acknowledgements}

We thank Michael Diehl, Alireza Ghaffari and Nandita Sharma for helpful discussion, and Kechun Zhang for help in preparing the patterned substrates. Supported by the NSF Center for the Science and Engineering of Materials at Caltech, NIH GM 62523 and EB 01971, an NIH predoctoral fellowship to SAM, a Whitaker Graduate Fellowship to JCL, and the Joseph J. Jacobs Institute for Molecular Engineering for Medicine.

\section{References}

1. Ekins RP. J Pharm Biomed Anal 1989;7:155-168. [PubMed: 2488616]Templin MF, Stoll D, Schrenk M, Traub PC, Vohringer CF, Joos TO. Trends Biotechnol 2002;20:160-166. [PubMed: 11906748]

2. Tan W, Desai TA. Biomaterials 2004;25:1355-1364. [PubMed: 14643610]Christman KL, EnriquezRios VD, Maynard HD. Soft Matter 2006;2:928-939.

3. Voldman J. Nat Mater 2003;2:433-434. [PubMed: 12876566]Shim J, Bersano-Begey TF, Zhu XY, Tkaczyk AH, Linderman JJ, Takayama S. Top Med Chem 2003;3:687-703.Corey JM, Feldman EL. Exp Neurol 2003;184:S89-S96. [PubMed: 14597331]Suh KY, Seong J, Khademhosseini A, Laibinis PE, Langer R. Biomaterials 2004;25:557-563. [PubMed: 14585705]Rozkiewicz DI, Kraan Y, Werten MWT, de Wolf FA, Subramaniam V, Ravoo BJ, Reinhoudt DN. Chem Eur J 2006;12:6290-6297.

4. Blawas AS, Reichert WM. Biomaterials 1998;19:595-609. [PubMed: 9663732]

5. Chin JW, Santoro SW, Martin AB, King DS, Wang L, Schultz PG. J Am Chem Soc 2002;124:90269027. [PubMed: 12148987]Chin JW, Martin AB, King DS, Wang L, Schultz PG. Proc Natl Acad Sci U S A 2002;99:11020-11024. [PubMed: 12154230]Bose M, Groff D, Xie JM, Brustad E, Schultz PG. J Am Chem Soc 2006;128:388-389. [PubMed: 16402807]

6. Kirshenbaum K, Carrico IS, Tirrell DA. ChemBioChem 2002;3:235-237. [PubMed: 11921403]Zhang KC, Diehl MR, Tirrell DA. J Am Chem Soc 2005;127:10136-10137. [PubMed: 16028902]

7. Di Zio K, Tirrell DA. Macromolecules 2003;36:1553-1558.

8. Heilshorn SC, Di Zio KA, Welsh ER, Tirrell DA. Biomaterials 2003;24:4245-4252. [PubMed: 12853256]Liu JC, Heilshorn SC, Tirrell DA. Biomacromolecules 2004;5:497-504. [PubMed: 15003012]Heilshorn SC, Liu JC, Tirrell DA. Biomacromolecules 2005;6:318-323. [PubMed: 15638535]

9. Ibba M, Soll D. Annu Rev Biochem 2000;69:617-650. [PubMed: 10966471]

10. Welsh ER, Tirrell DA. Biomacromolecules 2000;1:23-30. [PubMed: 11709838]

11. Pretsch, E.; Simon, W.; Seibl, J.; Clerc, T. Spectral Data for Structure Determination of Organic Compounds. Fresenius, W.; Huber, JFK.; Pungor, E.; Rechnitz, GA.; West, T., editors. SpringerVerlag; New York: 1989. p. I80

12. Costas C, Yuriev E, Meyer KL, Guion TS, Hanna MM. Nucl Acids Res 2000;28:1849-1858. [PubMed: 10756182]Cleary MA, Pendergrast PS, Herr W. Proc Natl Acad Sci U S A 1997;94:84508455. [PubMed: 9237997]

13. Engler A, Bacakova L, Newman C, Hategan A, Griffin M, Discher D. Biophys J 2004;86:617-628. [PubMed: 14695306]Ingber DE. Proc Natl Acad Sci U S A 2003;100:1472-1474. [PubMed: 12578965]

14. Zhang SG, Yan L, Altman M, Lassle M, Nugent H, Frankel F, Lauffenburger DA, Whitesides GM, Rich A. Biomaterials 1999;20:1213-1220. [PubMed: 10395390] 
A

CS5: MMMASMTGGCOMGHHHHHHMG(LD-GEEIQIGHIPREDVDYHLYPG((VPGVG, VPGFG(VPGVG) , VP), LE

$T 7$ tag

His tag

cell binding domain

elastin-like repeats

RGD: MMMASMTGGCOMGHHHHHHHDDDOK(LD-YAVTGRGDSPASSKPIA((VPGVG),VPGFG(VPGVG) ), VP), LE $77^{\text {tag }}$ His tag cut she cell binding domain elastin-like repeats

RDG: MMMASMTGGCOMGHHHHHHHDDDDK(LD.YAVTGRDGSPASSKPIA((VPGVG)VPGFG(VPGVG) J్ JV VP) LE

$T 7 \operatorname{tag}$

His tag cut site

cell binding domain

elastin-like repeats

B

C

D
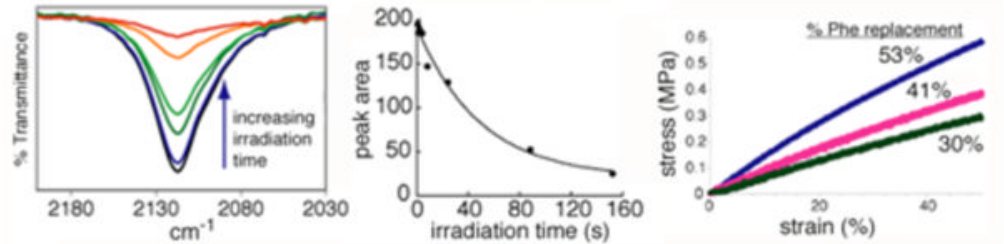

Figure 1.

Characteristics of aECM- $\mathrm{N}_{3}$ proteins. (A) Primary sequences of aECM-N $\mathrm{N}_{3}$ variants. (B) FTIR demonstrates loss of the characteristic azide asymmetric stretch as a function of irradiation time of CS5- $\mathrm{N}_{3}$ films. (C) Peak area vs. irradiation time yields a first order decay with $\mathrm{t}_{1 / 2}=34$ sec. (D) Uniaxial tensile testing of irradiated mold-cast films. 


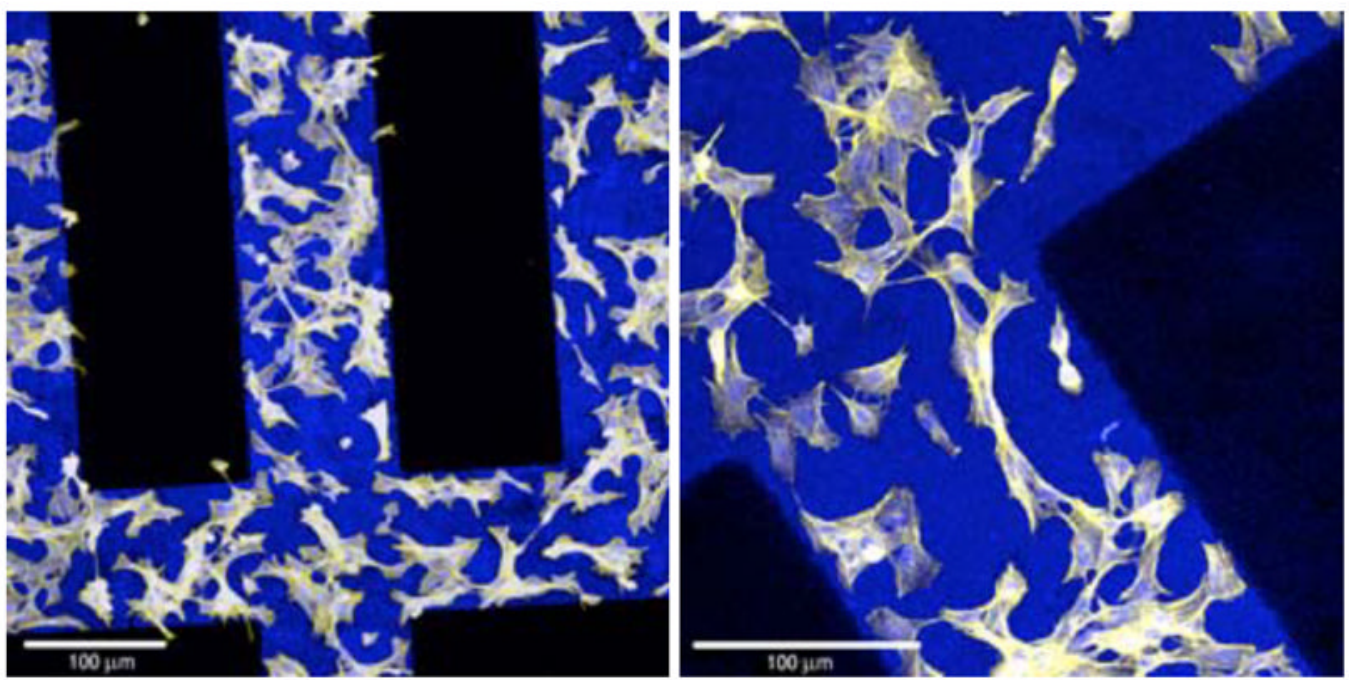

Figure 2.

Confocal microscopy of Rat-1 fibroblasts attached to photopatterned RGD-N 3 . Immunostaining with anti-T7 (blue) demonstrates colocalization of aECM-N 3 protein and cells (stained with rhodamine phalloidin (yellow)). Scale bars represent $100 \mu \mathrm{m}$. 
A

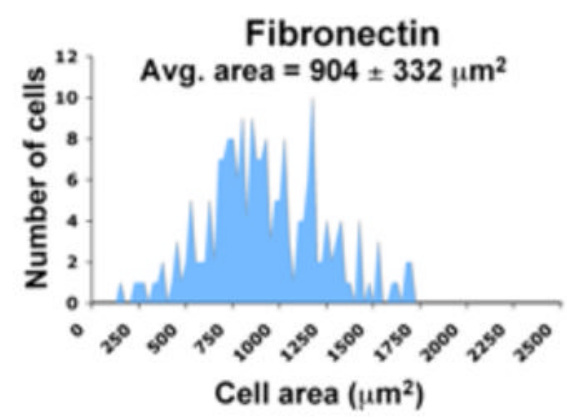

B

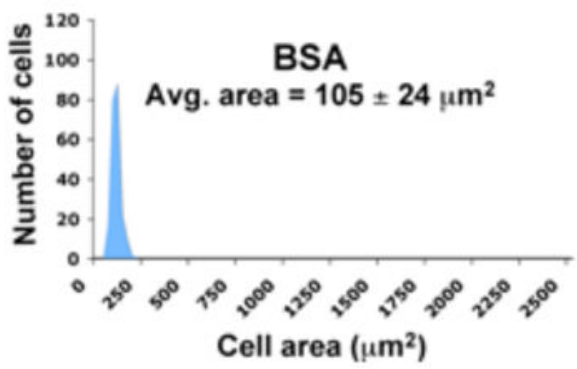

C

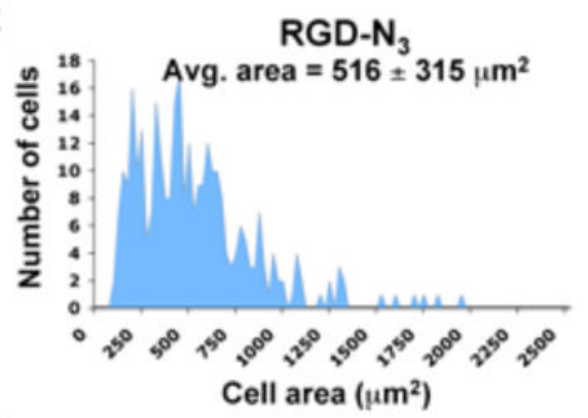

D

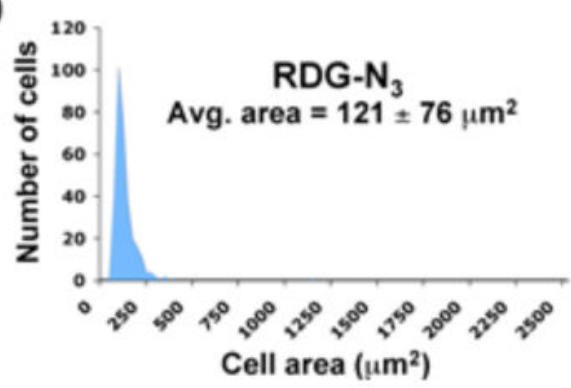

Figure 3.

Rat-1 fibroblast cell spread areas on (A) fibronectin, (B) BSA, (C) RGD-N 3 , and (D) RDG$\mathrm{N}_{3}$. RGD-N3 supports sequence-specific cell spreading. 